\title{
Economic Valuation of Chinese Dip Net Fishing on the Vembanad Lake- using Market Price Approach
}

\author{
V. Chandrasekar ${ }^{1 *}$, S. Murali Gopal ${ }^{2}$, A. Vidhyavathi², C. Jayanthi', \\ R. Sathy ${ }^{4}$ and Nikita Gopal
}

\author{
${ }^{1}$ ICAR - Central Institute of Fisheries Technology, Cochin 682 029, Inidia \\ ${ }^{2}$ Department of Agricultural Economics, (CARDS), TNAU-Coimbatore \\ ${ }^{3}$ Department of Agronomy, TNAU, Coimbatore - 641003 \\ ${ }^{4}$ Department of Physical Sciences and Information Technology, AEC \& RI, TNAU - \\ Coimbatore 641 003, India
}

*Corresponding author

\section{A B S T R A C T}

\section{Keywords}

Market price method, Vembanad lake, Chinese dip nets, Economic value

\section{Article Info}

Accepted:

20 June 2020

Available Online:

10 July 2020
The traditional Chinese dip net is symbolic of Kerala and is a major tourist attraction. These nets are operated along the banks of the lakes in the state, especially the Vembanad lake. It is categorized into three type i.e. big, medium and small. The economic value generated by the Chinese dip nets operated in the Vembanad lake was estimated using market price approach. The willingness-to-pay (WTP) is taken to be equal to market price of fish and shrimp catch and this was used as an indicator of the true value of a resource. The estimation of economic value generated from the Chinese dip net operations in Vembanad lake was about Rs.32.98 crores per annum, which gives livelihood to approximately around 4500 family beneficiaries.

\section{Introduction}

Chinese dip nets are dated to at least500 years back and is still operational in the Vembanad lake (locally called "Cheenavala"). They are shore operated lift nets installed on the land and operated along the backwaters of Kerala during high tide operated on the principle of counter weight balance. This is a sustainable way of fish harvesting with minimal environmental damage. It is considered a traditionally important livelihood fishing activity followed by the fishers residing in the bank of Vembanad lake Thomson (2003); Florence (2014); Rahman et al., (2016). As per a report of the Department of Fisheries, Government of Kerala in 1985-86 there were about 1915 licensed Chinese dip nets were under operation in the estuaries of Kerala (Inland fisheries statistics- 2007). According to Nair (1989), the total numbers of Chinese dipnets in the Vembanad lake was about 
4,823 and 65 percent of them were unregistered. In all about 4500 fisher families operate these Chinese dip nets along the bank of the lake. Though of late it is not a major source of income to the owners they still continue to operate the same with the help of native or migrant labour. The Department of fisheries stopped issuing licenses since decade. Kurup et al., (1993) observed that two stationary gears, the Chinese dip nets and stake nets contributed 72.5 percent of the total landings of Vembanad Lake of which stake nets contributing to 53 percent and Chinese dip nets 19.4 percent. The number of registered Chinese dip nets operated in the Vembanad lake was reported to be 1187, out of which 50 percent were operated in the Ernakulum district (PANFISH, 2011), of which about 234 come in the urban Cochin Corporation area. It is however observed that several of these gears operate in violation of legal provisions under the (Regulation of fishing with fixed engines (Stake nets, Chinese Nets etc, 1973). Based on the size, Chinese dip nets are categorized into 3 types big, medium and small. About 80 percent of Chinese dip nets were medium sized. These nets also adds to the scenic beauty of the lake and acts as a major attraction for the tourists who visit Kerala. This paper attempts the economic valuation of Chinese dip nets along the Vembanad lake using market price approach by using shrimp and fish catch value obtained per annum and also discusses operation details, profitability and issues in operation and the fishers willingness to pay (WTP) for the restoration of the ecosystem and its management.

\section{Materials and Methods}

\section{Study area}

Vembanad lake is situated in the state of Kerala and runs parallel to the west coast line of the state and is directly connected to the
Arabian Sea which allows sea water to mix with the wetland system. The geographical location of the Vembanad lake is between $09^{\circ} 00^{\prime}$ and $10^{\circ} 40^{\prime}$ north latitude and $76^{\circ} 00^{\prime}$ and $77^{\circ} 30^{\prime}$ east longitude. The water spread area is about $200 \mathrm{~km}^{2}$ in three districts of the state namely Ernakulum, Alappuzha and Kottayam. It extends to about $80 \mathrm{~km}$ from north in Ernakulum to south in Alappuzha and the width of the lake varies from $500 \mathrm{~m}$ to 4 $\mathrm{km}$ and depth from $<1 \mathrm{~m}$ to $12 \mathrm{~m}$. The Vembanad lake consists of streams, canals (both natural \& man-made), mangroves, lagoons etc. The rivers supplying fresh water to Vembanad lake are Periyar, Chithrapuzha, Muvattupuzha, Pamba, Manimala, Meenachil, and Muttar.

\section{Sampling}

The study area was selected based on the availability of Chinese dip nets operating in the village panchayats bordering Vembanad lake in3 district namely Ernakulum, Alappuzha and Kottayam. The total respondents selected for the study was 30 who were operating registered Chinese dip nets. Primary survey was carried out using wellstructured questionnaire through direct personal interviews on socio-economic characteristic of the households, their initial investment, operational details including labour cost and revenue generated which was used for the economic valuation of Chinese dip nets. Secondary data about number of registered Chinese dip nets present in the borders of Vembanad lake were collected at both district and panchayat level fisheries department (Fig. 1).

\section{Market price approach model description}

Market-based valuation methods rely on market price to evaluate the flow of resources and also existing stocks. This method uses the actual price as an indicator of the true value of 
a resource. Here, willingness-to-pay (WTP) is taken to be equal to market price. Many ecosystem services provide benefits to society but have no direct market value and therefore a money value attached to it. In wellfunctioning markets preferences and marginal cost of production are reflected in a market price, which implies that these can be taken as accurate information on the value of commodities. Barbier et al., (1996); King et al., (1999); Struip et al., (2002), Market pricebased approaches are used to obtain the value of provisioning services and commodities such fish and shrimp that are often sold in fish markets. The price of a commodity times the marginal product of the ecosystem service is an indicator of the value of the service. Consequently, market prices can also be good indicators of the value of the ecosystem service that is being studied. In this study the gross return value obtained per annum from the individual Chinese dip nets operating on the Vembanad lake was estimated using quantity of fish and shrimp catch of different seasons in a year and its average market price. The benefits obtained by using Chinese dip nets for their livelihoods was measured using market valuation approach and was calculated using the formula

$$
V_{i}=\sum_{i=1}^{n}\left(P_{i} Q_{i}\right)
$$

Where, $V_{i}=$ Value of the $\mathrm{i}^{\text {th }}$ resource obtained from lake (₹/unit/year)

$P_{i}=$ price of the $\mathrm{i}^{\text {th }}$ resource $(₹ / \mathrm{Kg})$

$Q_{i}=$ quantity of $\mathrm{i}^{\text {th }}$ resource $(\mathrm{Kg})$

$\mathrm{i}=$ Resource catch (fish/shrimp)

\section{Results and Discussion}

Initially Chinese dip nets were initially completely made up of wooden structures mainly teak wood for the arms and big poles, which are more lasting and suitable for operating in the backwaters and bamboo poles were used for side walk. The base pillar was normally fabricated using80 to 100 year old coconut wood. The wooden structure requires maintenance periodically and certain wooden parts may require replacement. Over a period of time all the wooden parts of Chinese dip nets have been replaced by galvanized steel pipes and concrete pillars. These changes were mainly due to high cost of natural timber and high maintenance costs. The nonavailability of skilled labour to set these Chinese dip nets was another limiting factor. Further, reduction in overall shrimp and fish catch and increase in the labour cost worsened the situation (Asha et al., 2014). Though it has become increasingly uneconomical to operate the traditional wooden Chinese dip nets they are still maintained in few areas, particularly in Fort Kochi in Ernakulum district, mainly for tourist.

About $80 \%$ of the sampled fishing units were medium units and the age of fishermen respondents ranged from 30-50 years majority of whom were illiterate (54\%). Around $43 \%$ of families have less than 4 members. About $63 \%$ of the Chinese dip nets units generate annual income of less than one lakh (Table 1).

\section{Operational details}

Based on size, Chinese dip nets were classified into 3 categories, large medium and small. The initial investment varies according to the size from Rs 0.75 to 1.5 lakhs per unit for small, Rs 1.5 lakhs to 2.5 lakhs for medium and above 2.5 lakhs for large units. The units are to be registered under the Department of Fisheries of the state. The labour cost is the major part in the operational expenses of the Chinese dip nets as it requires a team of 5-6 fishermen for a bigger unit. Medium size fishing nets can be operated by a one person if it is motorized or maximum 2 persons if it depends only on manual labour. 
The Chinese dip nets are operated by the owner or labourers depending upon the catch. If the catch value is more than the daily wage rate, then the labour about $50 \%$ of whom are migrant labour are willing to operate and give the owner's share. Chinese dip nets are not allowed to be installed near the lake bar mouth and in the middle of the estuary. Even the distances between two adjoining Chinese dip nets have been specified as not less than 30 meters. In some areas there is a system of shifting of operational timings every alternate day. Normally the households who own the land adjacent the water bodies can fix the Chinese dip nets in front of their property. Rent is given by other persons who want to fix and operate their dip nets in water bodies adjacent to another person's property.

Normally the medium sized units are used for catching of fishes and shrimps. It is operated during night for shrimp by attracting it using lantern or 200 watts incandescent bulb. The operation of the net also follows the occurrence of high and low tide. Once the net is lifted the caught shrimp and fishes are removed with the help of a scoop net. Depending on the availability of shrimps and fishes in the lake they also operate in the day time by dipping the net for short periods of about 5 to 10 minutes in frequent intervals and pulling the rope for lifting the net as and when required (Pillai, 2016).

The average quantity of fish catch by the large Chinese dip nets was about 2 to $5 \mathrm{~kg}$ per day. Normally it used to catch penaeid prawns such as Metapenaeus dobsoni (brown shrimp), $M$. affinis (Indian prawn), $M$. monoceros (King shrimp) and Penaeus indicus (Indian white shrimp) and fishes like Etroplus suratensis (pearl spot), Engraulidae sp. (Anchovies), Mugilidae sp. (mullets), Lates calcarifer (Kalanji), Synodontidae sp. (Lizard fish), Siluriformes sp. (Cat fish), Chanos chanos (milk fish), etc.
The Chinese dip nets were operated by both local or migrant labour on share basis which varies from 50 to 75 percent depending upon the total value of catch, Table 2 shows the cost benefit analysis for the different categories of the Chinese dip nets which has been used for the economic valuation of the units operated in the Vembanad lake, The cost of labour is not fixed and is dependent on the total value of catch (shrimps and fishes) during their operating hours. The average annual quantity of shrimp and fishes caught during both peak and lean seasons were collected from sample units. The data were used to calculate 'with' and 'without' labour cost scenario and it shows drastic change in economic benefits. In case of "with labour cost", value of BCR is less than 1, NPV and IRR are negative. Whereas in case of "without labour cost" condition positive returns are observed for BCR (varies from 2.0 to 2.5), NPV (varies from 2.2 to 10 lakhs) and IRR (varies from 18 to 40 percent). This shows that if it is operated using family labour, it is a profitable venture. But many of the families will not operate use this as the reserve price is more than that of the migrant labourers' wage, and they prefer to go for other jobs for higher wages. It can however be inferred that if the return from fish and shrimp sale does not meet the labour cost during the day of operation, operating the units is not economical.

The annual total economic value of the shrimp and fish harvested using Chinese dip nets situated on the banks of Vembanad lake in all the border village panchayat were estimated using the market price approach which comes to about Rs.11.55 crores (Table 3 ). This value is arrived taking into account only the registered units. If we include the unregistered ones (as per the study Nair, 1989). The value is about Rs.32.98 crores, which gives livelihood to approximately around 4500 family beneficiaries. Shrimp 
alone contribute around 85 percent to this value. The shrimp are supplied to the local markets or pealing sheds situated in Alappuzha and Ernakulum district.

Table.1 Annual income of the Chinese dip nets operating in the Vembanad lake

\begin{tabular}{|l|r|r|r|r|}
\hline \multicolumn{1}{|c|}{ Particulars } & \multicolumn{1}{c|}{$\begin{array}{c}\text { Large } \\
\text { CFN }\end{array}$} & $\begin{array}{c}\text { Medium } \\
\text { CFN }\end{array}$ & \multicolumn{1}{c|}{$\begin{array}{c}\text { Small } \\
\text { CFN }\end{array}$} & Total \\
\hline Less than 1 lakhs & $1(14 \%)$ & $15(71 \%)$ & $2(100 \%)$ & $\mathbf{1 8 ( 6 0 \% )}$ \\
\hline $\mathbf{1}$ to 2 lakhs & $3(43 \%)$ & $6(29 \%)$ & $0(0 \%)$ & $\mathbf{9 ( 3 0 \% )}$ \\
\hline $\mathbf{2}$ to 3 lakhs & $2(29 \%)$ & $0(0 \%)$ & $0(0 \%)$ & $\mathbf{2 ( 7 \% )}$ \\
\hline More than 3 lakhs & $1(14 \%)$ & $0(0 \%)$ & $0(0 \%)$ & $\mathbf{1 ( 3 \% )}$ \\
\hline Total & $\mathbf{7 ( 1 0 0 \% )}$ & $\mathbf{2 1 ( 1 0 0 \% )}$ & $\mathbf{2 ( 1 0 0 \% )}$ & $\mathbf{3 0}(\mathbf{1 0 0})$ \\
\hline
\end{tabular}

Table. 2 Cost and return investment on different size of Chinese dip nets operated with \& without labour cost in the Vembanad lake

\begin{tabular}{|l|r|r|r|}
\hline \multicolumn{1}{|c|}{ Particulars } & \multicolumn{1}{|c|}{$\begin{array}{c}\text { Large } \\
\text { CFN }\end{array}$} & $\begin{array}{c}\text { Medium } \\
\text { CFN }\end{array}$ & \multicolumn{1}{|c|}{$\begin{array}{r}\text { Small } \\
\text { CFN }\end{array}$} \\
\hline Initial Investment (Rs) & 480000 & 209000 & 103000 \\
\hline Annual return (Rs) & 219000 & 95438 & 57938 \\
\hline \multicolumn{1}{|c|}{ Without labour cost } \\
\hline Total annual cost (Rs) & 120108 & 55056 & 27124 \\
\hline Annual net profit (Rs) & 117288 & 47254 & 34986 \\
\hline Benefit cost ratio (BCR) & 2.2 & 2.0 & 2.5 \\
\hline Net Present Value (NPV) & 1007168 & 359790 & 224843 \\
\hline $\begin{array}{l}\text { Internal Rate of Return } \\
\text { (IRR) \% }\end{array}$ & $40 \%$ & $27 \%$ & $18 \%$ \\
\hline & With labour cost & & \\
\hline Total annual cost (Rs) & 273408 & 112318 & 61886 \\
\hline Annual net profit (Rs) & -54408 & -16881 & -3949 \\
\hline Benefit cost ratio (BCR) & 0.80 & 0.85 & 0.94 \\
\hline Net Present Value (NPV) & -881488 & -345685 & -203432 \\
\hline $\begin{array}{l}\text { Internal Rate of Return } \\
\text { (IRR) \% }\end{array}$ & Neg & Neg & Neg \\
\hline
\end{tabular}


Table.3 Economic value of annual fish and shrimp harvested by Chinese dip nets in the Vembanad lake Value in (Lakhs)

\begin{tabular}{|c|c|c|c|c|c|}
\hline Sl.no & Particulars & $\begin{array}{l}\text { Large } \\
\text { CFN }\end{array}$ & $\begin{array}{l}\text { Medium } \\
\text { CFN }\end{array}$ & $\begin{array}{c}\text { Small } \\
\text { CFN }\end{array}$ & Total \\
\hline & \multicolumn{5}{|c|}{ ERNAKULAM DISTRICT } \\
\hline 1 & Fishes & 85.86 & 9.65 & 9.42 & 104.93 \\
\hline \multirow[t]{3}{*}{2} & Shrimps & 10.80 & 437.00 & 26.51 & 474.30 \\
\hline & Sub-total & 96.66 & 446.65 & 35.92 & 579.23 \\
\hline & \multicolumn{5}{|c|}{ ALAPPUZHA DISTRICT } \\
\hline 1 & Fishes & 33.39 & 8.66 & 8.05 & 50.10 \\
\hline \multirow[t]{3}{*}{2} & Shrimps & 4.20 & 392.18 & 22.66 & 419.03 \\
\hline & Sub-total & 37.59 & 400.84 & 30.71 & 469.13 \\
\hline & \multicolumn{5}{|c|}{ KOTTAYAM DISTRICT } \\
\hline 1 & Fishes & 11.13 & 1.90 & 1.52 & 14.55 \\
\hline \multirow[t]{3}{*}{2} & Shrimps & 1.40 & 85.91 & 4.28 & 91.58 \\
\hline & Sub-total & 12.53 & 87.80 & 5.79 & 106.13 \\
\hline & \multicolumn{5}{|c|}{ TOTAL VEMBANAD ESTURAINE } \\
\hline 1 & Fishes & 130.38 & 20.21 & 18.98 & 169.58 \\
\hline 2 & Shrimps & 16.40 & 915.08 & 53.44 & 984.91 \\
\hline & Grand total & 146.78 & 935.29 & 72.42 & 1154.49 \\
\hline
\end{tabular}

Figure.1 Panchayat-wise registered number of Chinese dip nets operated along the Vembanad lake, Kerala

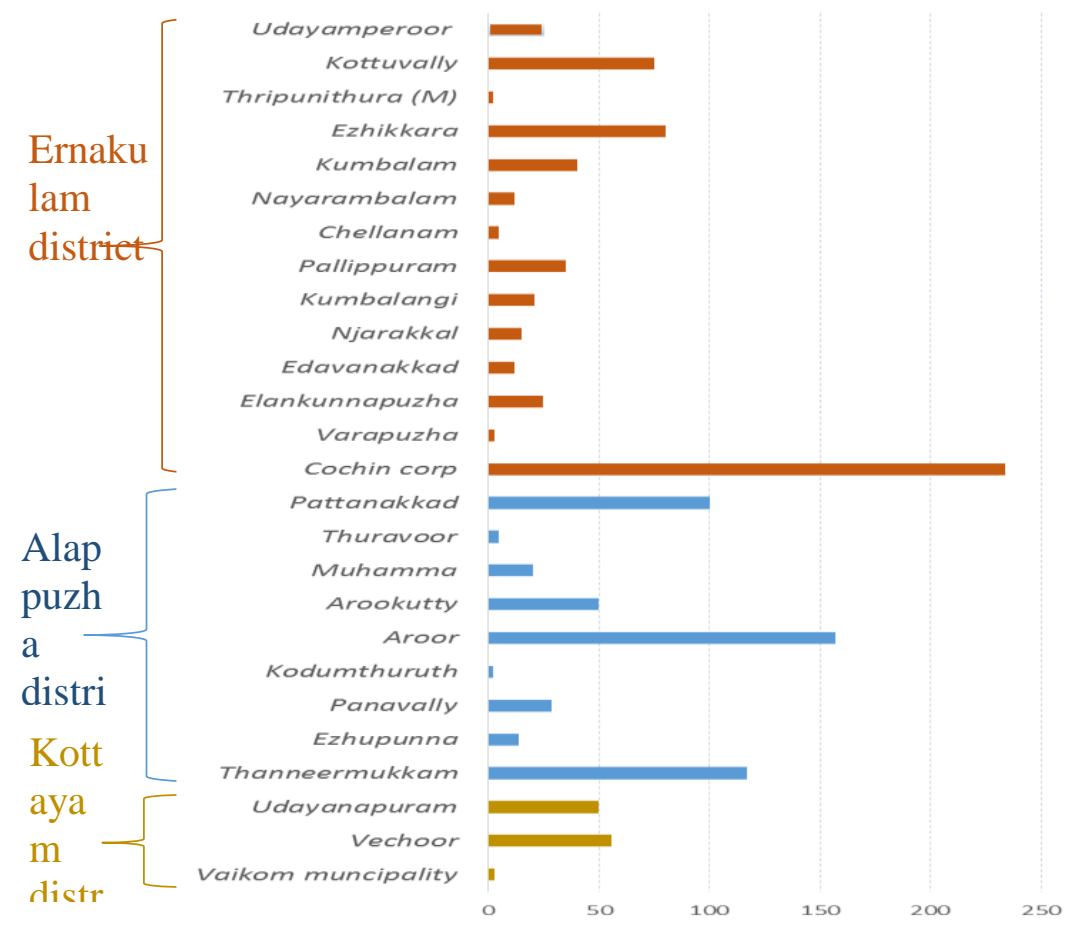




\section{Issues Chinese dip net fishery}

As mentioned earlier, the Department of Fisheries has stopped issuing new license to Chinese dip nets operating in the Vembanad lake making several units illegal. Shrimp catches have reduced drastically due to the accumulations of sediments due to dredging as well as discharge of waste from various sources such seafood processing factories, peeling sheds and industrial effluents, pepper factory chemical waste, paper mill, Cochin refineries and domestic and municipal waste drained into the estuary which has affected the quality of the water. Hindrance to the fishing operation by the aquatic weeds Eichhornia crassipes (water hyacinth)has also affected the fauna and other biological life terms. In addition to these periodic dredging in the harbours and shipping channels also threaten to fishery (Gopinath and Qasim, 1971).

\section{Tourism as an alternate revenue generation activity}

There is a general decline in fish catch along with poor returns in the Chinese dip nets fishery. The traditional ways of operation still continue except for few changes in the construction. The traditional operation of dip nets are however very attractive to tourists, especially foreign tourist. In tourist spots like Fort Kochi in Ernakulam this is generating revenue by allowing visitors to operate the units this can thus form an alternative avenue of income for the fishes which has to be carefully integrated into tourism plans, especially as tourism hubs.

It is concluded, about 4500 inland fishers' livelihoods depend on Chinese dip net fishing. Majority of these units are now unlicensed as the state fisheries department has stopped issuing fresh licenses though it is a relatively sustainable fishing method. It has become increasingly unprofitable with traditional licenses obtained from their ancestors, fishers have been continuing the activity. This is an age old traditional fishing technique needs to be sustained. There is no fixed wage structure and is based on daily catches and share system. Improvements to make the design more effective new revenue generation concepts like tourism villages will generate additional revenue to the beneficiaries which can also be used for management of the estuary.

\section{References}

Asha Chalil Veedu, Payattukattil Sukumaran Suson, Cleetus Irumpanath Retina, Sivasankaran Bijoy Nandan (2014), "Decline in Diversity and Production of Exploited Fishery Resources in Vembanad Wetland System- Strategies for Better Management and Conservation", Open Journal of Marine Science, 2014, 4, 344-357.

Barbier, E.B., M. Acreman and D. Knowler (1996) "Economic Valuation of Wetlands: A guide for Policy Makers and Planners". Ramsar Convention on Wetlands.

Florence M. A. and D. Rajasenan (2014), "Sustainability and livelihood issues of Vembanad coastal wetland ecosystem based fishermen communities in Kerala: a multi-dimensional scaling approach", Asian African journal of economics and econometrics - New Delhi : Serials Publ., Vol. 14.2014, 1, p. 89-98.

Gopinathan, C.K. and S.Z, Qasim (1971). Slating in navigational channels of the Cochin Harbour area. J. mar, biol. Ass. India, 13 (1): 14-26.

Inland Fisheries Statistics of Kerala (2007), Department of Fisheries, Government of Kerala.

King D. and Mazzota (1999) Ecosystem valuation website: 
(www.ecosystemvaluation.org).

Kurup, B. M., Sankaran, T. M., Rabindranath, P. and Sebastian, M. J. (1993). Seasonal and Spatial Variations in Fishing Intensity and Gear-wise Landings of the Vembanad Lake. Fish. Technol. 30, pp $15-20$.

Nair, B. (1989), 'Report of the Expert Committee on Marine Fishery Resources Management in Kerala', A Report Submitted to the Government of Kerala. Thiruvananthapuram.

PANFISH Book (2011), Fisheries statistics, Department of Fisheries, Kerala.

Pillai. Lakshmi S, G. Maheswarudu, P. K. Baby and A. P. Dineshbabu (2016), An appraisal of Chinese dip net fishery off Vypin, Kerala. Marine Fisheries Information Service, $T \& E$ Ser., No.
227.

Rahman, Ramees M., Athira. N. R., and M. Meera Bai (2017). Economic evaluation of the two major traditional fishing techniques in vembanad estuary, Kerala, Proceedings of National Research Conference on Commerce Management and Social Sciences (NRCCMS'17) $p$. 313-317.

Struip, M.A.M., Baker, C.J. and Oosterberg, W. (2002). The Socioeconomics of Wetlands, Wetlands International and Riza, The Netherlands.

Thomson, K. (2003), Economic and Social Management of Estuarine Biodiversity in the West Coast of India; Theme Marine Ecosystem and Sustainability, EERC Working Paper Series, MES- 4, 282 Pages.

\section{How to cite this article:}

Chandrasekar, V., S. Murali Gopal, A. Vidhyavathi, C. Jayanthi, R. Sathy and Nikita Gopal. 2020. Economic Valuation of Chinese Dip Net Fishing on the Vembanad Lake- using Market Price Approach. Int.J.Curr.Microbiol.App.Sci. 9(07): 2365-2372. doi: https://doi.org/10.20546/ijcmas.2020.907.276 